\title{
The Limits of Claim Differentiation
}

\author{
By Mark A. Lemley ${ }^{\dagger}$
}

TABle OF ConTENTS

I. INTRODUCTION

II. CANONS OF CLAIM CONSTRUCTION

III. CLAIM DIFFERENTIATION AND ITS PROBLEMS

IV. PROPERLY APPLYING CLAIM DIFFERENTIATION 1396

V. CONCLUSION 1401

\section{INTRODUCTION}

The process of claim construction is the most important part of patent litigation. Courts employ a number of rules, or canons, to reach an understanding of what patent claims mean. Of these, the doctrine of claim differentiation has arguably had the most significant impact on claim construction. Understood most broadly, the claim differentiation doctrine provides that no two claims in the same patent should be interpreted to have the same scope.

As a general matter, applying the doctrine of claim differentiation results in broader constructions of patent claims, because it is most commonly used to prevent defendants from limiting a broad genus claim to the range of embodiments actually disclosed or more explicitly recited in other claims. Sometimes this is the right result, because defendants are improperly seeking to limit broader genus claims to the preferred embodiments disclosed in the specification. But at other times it leads to problematic results by expanding claims to cover things the patentee never intended.

(C) 2008 Mark A. Lemley.

$\dagger$ William H. Neukom Professor, Stanford Law School; of counsel, Keker \& Van Nest LLP. I represented Google in the case between Yahoo! and Google discussed in this article, so I want to emphasize that my opinions are my own, and not those of my firm or my clients. I am grateful to Dennis Crouch, Daralyn Durie, Rose Hagan, Leo Lam, and Joe Miller for comments on an earlier draft and to Sarah Craven for research assistance above and beyond the call of duty on the empirical aspects of this study. 
In this Article, I conduct an empirical review of claim differentiation decisions in the Federal Circuit and in the district courts, and I suggest limiting principles that can be used to guide courts in their application of the doctrine.

\section{CANONS OF CLAIM CONSTRUCTION}

The process of claim construction-determining the meaning of patent claims - is central to patent litigation. Once patent claims are construed in a "Markman hearing," cases generally either settle or are resolved on summary judgment. ${ }^{2}$ Accordingly, courts and commentators have paid a great deal of attention to both the process of claim construction and the interpretive sources courts can use to determine the meaning of patent claims. ${ }^{3}$ Indeed, the Federal Circuit recently decided Phillips v. $A W H$ Corp. en banc to settle the much-debated question of when it is acceptable to rely on the text of the patent, the prosecution history, dictionaries, and expert testimony in construing patent claims. ${ }^{4}$

1. So called because of the Supreme Court decision in Markman v. Westview Instruments, Inc., 517 U.S. 370 (1996), which held that claim construction was a question of law for the judge.

2. For efforts to estimate settlement rates in patent cases, which are somewhere between $80 \%$ and $98 \%$ of all cases, see William M. Landes, An Empirical Analysis of Intellectual Property Litigation: Some Initial Preliminary Results, 41 Hous. L. REV. 749 (2004); Jay P. Kesan \& Gwendolyn G. Ball, How Are Patent Cases Resolved? An Empirical Examination of the Adjudication and Settlement of Patent Disputes, 84 WASH. U. L. REV. 247 (2006). There are only about 100 patent trials a year out of roughly 3000 suits filed. For some evidence of the increase in summary judgment grants after Markman, particularly in favor of defendants, see John R. Allison \& Mark A. Lemley, The (Unnoticed) Demise of the Doctrine of Equivalents, 59 STAN. L. REV. 955 (2007).

3. Among the many scholarly articles on claim construction, see, for example, Symposium, 9 LewIS \& ClaRK L. REV. 1 (2005); Ben Hattenbach, Chickens, Eggs and Other Impediments to Escalating Reliance on Dictionaries in Patent Claim Construction, 85 J. Pat. \& Trademark OfF. SoC'Y 181 (2003); Joseph Scott Miller \& James A. Hilsenteger, The Proven Key: Roles and Rules for Dictionaries at the Patent Office and the Courts, 54 AM. U. L. REV. 829 (2005); Craig Allen Nard, A Theory of Claim Interpretation, 14 HARV. J.L. \& TECH. 1 (2000); Kristen Osenga, Linguistics and Patent Claim Construction, 38 RuTgers L.J. 61 (2006); R. Polk Wagner \& Lee Petherbridge, Is the Federal Circuit Succeeding? An Empirical Assessment of Judicial Performance, $152 \mathrm{U}$. PA. L. REV. 1105 (2004).

4. Phillips v. AWH Corp., 415 F.3d 1303 (Fed. Cir. 2005) (en banc). Despite the court's broad agreement on the hierarchy of interpretive sources, which focuses on the patent specification and the context of the invention at the time it was made, the court continues to disagree about the application of those rules to specific cases. Indeed, Hal Wegner has found that there are three times as many dissents in claim construction cases after Phillips as before. See Philip Brooks' Patent Infringement Updates, The Call for 
Surprisingly, courts and commentators have paid less attention to the canons of claim construction. Courts use a number of such rules in applying the interpretive sources to reach an understanding of what patent claims mean. For example, courts may rely on the examples given in the specification to understand and interpret the meaning of claim language, but they may not use examples to read new limitations into those claims. ${ }^{5}$ Courts generally should not interpret a claim in a way that excludes the preferred embodiment. ${ }^{6}$ Courts have also long applied a canon that patent claims should be construed to preserve their validity, ${ }^{7}$ though that canon is in some disfavor today and is applied only in marginal cases. ${ }^{8}$ There is even a "tie-breaker" canon that provides that if two alternative interpretations are equally plausible, the court will choose the narrower interpretation to avoid unfair surprise to the public. ${ }^{9}$

The doctrine of claim differentiation is the canon that has arguably had the most significant impact on claim construction. Used in sixty-nine reported Federal Circuit decisions and many more district court opinions in the past nine years, claim differentiation is based on the presumption that patent applicants almost always write multiple claims in an effort to get several different tries at capturing their invention in words. ${ }^{10}$ Patentees often hedge their bets by "nesting" multiple claims, drafting broad claims that defendants are likely to infringe, but which courts are more likely to find invalid, as well as narrow claims that cover less ground, but which courts are therefore more likely to find valid. The claim differentiation

Claim Construction Improvement, http://infringement.blogs.com/philip_brooks_patent_i nfr/2006/12/the_call_for_cl.html (Dec. 8, 2006) (citing Harold C. Wegner, The NonPrecedential Claim Construction Black Hole, at 36 (2006), http://www.patenthawk.com/ blog_docs/060814_BlackHoleClaimConstruction_Wegner.pdf.).

5. See, e.g., Renishaw PLC v. Marposs Societa' Per Azioni, 158 F.3d 1243, 1248 (Fed. Cir. 1998). 1999).

6. Burke, Inc. v. Bruno Indep. Living Aids, Inc., 183 F.3d 1334, 1341 (Fed. Cir.

7. Modine Mfg. Co. v. U.S. Int'l Trade Comm'n, 75 F.3d 1545, 1557 (Fed. Cir. 1996). 1999).

8. Phillips, 415 F.3d at 1327; Rhine v. Casio, Inc., 183 F.3d 1342, 1345 (Fed. Cir.

9. Athletic Alternatives, Inc. v. Prince Mfg., Inc., 73 F.3d 1573, 1581 (Fed. Cir. 1996); $c f$. Northern Telecom Ltd. v. Samsung Elecs. Co., 215 F.3d 1281, 1295 (Fed. Cir. 2000) (noting the limited nature of this tie-breaker rule).

10. See John R. Allison \& Mark A. Lemley, Who's Patenting What? An Empirical Exploration of Patent Prosecution, 53 VAND. L. REV. 2099, 2149 tbl.5 (2000) (finding that patents have 14.87 claims on average, and a median of 12 claims). 
doctrine in its broadest reading provides that no two claims in the same patent should be interpreted as having the same scope. ${ }^{11}$

The doctrine seems to flow from a parallel doctrine of statutory construction that rejects statutory interpretations that would render a provision redundant or superfluous, presumably because Congress would not knowingly pass the same statute twice. ${ }^{12}$ Similarly, because the Patent and Trademark Office (PTO) charges applicants a fee for each claim, and because applicants must pay attorneys to draft those claims, the law presumes that applicants do not waste their money by drafting two claims that mean exactly the same thing. ${ }^{13}$ As a result, courts generally reject an interpretation of a claim term that renders that claim redundant of another claim. $^{14}$

\section{CLAIM DIFFERENTIATION AND ITS PROBLEMS}

Courts rely heavily on the doctrine of claim differentiation. In the last ten years alone, federal courts have done so hundreds of times. ${ }^{15}$ As a gen-

11. See, e.g., Ecolab, Inc. v. Paraclipse, Inc., 285 F.3d 1362, 1375 (Fed. Cir. 2002). This version is the one that seems to be applied in the PTO, for example. See 37 C.F.R. $\S 1.75(b)$ (2006) ("More than one claim may be presented provided they differ substantially from each other.").

12. The legal maxim is lex rejicit superflua, pugnantia, incongrua ("[T]he law rejects superfluous, contradictory, and incongruous things."). FRANCIS BENNION, STATUTORY INTERPRETATION $\S 316$, at 776 (3d ed. 1997). For applications, see, for example, South Carolina v. Catawba Indian Tribe, Inc., 476 U.S. 498, 510 n.22 (1986) ("It is an 'elementary canon of construction that a statute should be interpreted so as not to render one part inoperative."'); Mackey v. Lanier Collection Agency \& Service, Inc., 486 U.S. 825,837 (1988) ("'W]e are hesitant to adopt an interpretation of a congressional enactment which renders superfluous another portion of that same law"). But see CAL. CIV. CODE $\S 3537$ (West 1997) ("Superfluity does not vitiate.").

13. Cf. Smith \& Nephew, Inc. v. Ethicon, Inc., 276 F.3d 1304, 1310 (Fed. Cir. 2001) (relying on patent prosecution practice to justify the claim differentiation doctrine).

14. Cf. Nomos Corp. v . BrainLAB USA, Inc., 357 F.3d 1364, 1368 (Fed. Cir. 2004) (referring to claim differentiation as "a guide, not a rigid rule").

15. An analysis of 136 recent Federal Circuit and district court cases that dealt with the issue of claim differentiation illuminates judicial application of claim differentiation. Ten did not ultimately decide the merits of the claim differentiation question, leaving 126 cases. Of those, 90 , or $71.4 \%$, applied the doctrine in interpreting the claim; only 36 did not apply the doctrine.

I included all Federal Circuit cases dealing with claim differentiation between June 1998 and October 2006 and a sampling of district court cases between June 2000 and October 2006. For each year, I selected between 7-10 district court cases (though 15 for 2006, and only four cases for 2000) by going down the chronological order list retrieved by Westlaw using the term "claim differentiation." I recognize the statistical limits of this selec- 
eral matter, applying the doctrine results in broader constructions of patent claims, because it is most commonly used to prevent defendants from limiting a broad genus claim to the narrower range of embodiments actually disclosed or more explicitly recited in other claims. When defendants are indeed improperly seeking to limit broader genus claims to the examples disclosed in the specification, this is the right result. But at other times the doctrine can lead courts astray, causing them to expand the scope of one claim beyond what the patent supports merely to distinguish that claim from another.

For example, in Phillips $v$. $A W H$, the court interpreted a claim to encompass an embodiment of an invention that would not achieve the purpose of the invention. At issue in Phillips was the term "baffles" in a claim for a bulletproof prison wall. "Baffles" are metal reinforcements attached to the interior of the wall to prevent bullets from passing through the wall entirely. Because a metal support perpendicular to the wall will stop a bullet only if the bullet enters the wall directly into the support end-on, "baffles" are normally attached at oblique angles to the wall. Nevertheless, the Federal Circuit held en banc that "baffles" included metal supports oriented at ninety degrees to the wall because a separate claim in the patent referred to baffles "projecting inwardly from the outer shell at angles tending to deflect projectiles that penetrate the outer shell."16 The court reasoned that because one claim specified that baffles projected at particular angles, the characteristic of projecting at such angles could not be inherent in the term "baffles" itself. The problem with this interpretation is that the purpose of a "baffle" in the invention was to stop bullets from penetrating the wall. As Judge Lourie's dissent correctly observed, a metal support attached at a right angle to the wall will stop a bullet only in the rare instances where the bullet is fired at an extremely acute angle to the wall or the bullet happens to hit right at the point where the baffle meets the wall. A steel support oriented at ninety degrees fails to achieve the purpose of the invention except by accident. ${ }^{17}$ The doctrine of claim differentiation led the court astray in this case.

The problem with the doctrine of claim differentiation is that it proceeds from a false premise. It may or may not be reasonable for courts to presume that Congress does not intend to pass redundant statutes. ${ }^{18}$ But

tion method; I use it not to prove any fact about district court or Federal Circuit decisions but to get a flavor of the ways the claim differentiation doctrine has been used.

16. Phillips v. AWH Corp., 415 F.3d 1303, 1309-10 (Fed. Cir. 2005) (en banc).

17. Id. at 1329 (Lourie, J., dissenting).

18. Actually, I am skeptical that Congress never passes redundant legislation. Legislators may well have incentives to pass redundant statutes in order to score points with 
patents are not like statutes. Patent applicants who draft multiple claims quite often are trying to be redundant. A patentee with sixty claims does not have sixty different inventions; indeed, patent law prevents an applicant from prosecuting different inventions in the same application. ${ }^{19}$ Rather, patent applicants draft multiple claims because writing words to define ideas is an inherently difficult and uncertain process, ${ }^{20}$ and taking multiple bites at the apple gives patentees a greater chance of successfully capturing their single invention in words. Although patentees sometimes draft different patent claims to cover broader or narrower ranges, in the "nesting" approach described above, it is more common for them to write multiple claims using different words to define a single attribute or embodiment of their invention.

When a patentee makes multiple attempts to define a particular attribute of an invention, the canon of claim differentiation is likely to lead courts astray. If the patentee is using different words to mean the same thing, a rule that requires each set of words to have its own unique meaning creates artificial distinctions not intended by the patentee, and accordingly means the court has likely misinterpreted at least one of the claims. The doctrine also leads to a fruitless search for gradations in meaning that simply may not exist. And by requiring courts to give a broader meaning to one claim to differentiate it from another, claim differentiation tends to artificially expand the scope of patent claims.

A recent patent dispute between Yahoo! and Google demonstrates how the canon of claim differentiation can lead to such absurd results. Yahoo! holds a patent on the arrangement of search results based on the lister's willingness to pay per click. ${ }^{21}$ Yahoo!'s predecessor Overture sued Google for infringing that patent. Google argued that it did not order its ad results in the way required by Overture's patent. The question in the case was how to interpret the claim language covering the ordering of search list-

voters or to embarrass adversaries. The statutory interpretation canon may have more to do with discouraging duplicative legislation than with accurately understanding what the legislature has done.

19. 35 U.S.C. $\S 121(2000)$.

20. Festo Corp. v. Shoketsu Kinzoku Kogyo Kabushiki Co., 535 U.S. 722, 731 (2002) ("Unfortunately, the nature of language makes it impossible to capture the essence of a thing in a patent application."); Dan L. Burk \& Mark A. Lemley, Quantum Patent Mechanics, 9 LeWIS \& ClARK L. REV. 29 (2005); Jim Bessen \& Michael Meurer, If You Can't Tell the Boundaries, Then It Ain't Property, in INNOVATION AT RISK (forthcoming 2008), available at http://researchoninnovation.org/dopatentswork/dopat3.pdf.

21. U.S. Patent No. 6,269,361 (filed May 28, 1999). 
ings. ${ }^{22}$ Different claims variously covered ordering search listings "in accordance with" the amount bid (independent claim 1), in an order "determined using" bid amounts (independent claim 14), in a strict order of "ordinal rank value" from highest to lowest bid (claim 18, which depended from claim 14), "in an order corresponding to" the amount bid (independent claim 30), and once again in a strict order of "ordinal rank value" from highest to lowest bid (claim 46, which depended from claim 30). How can a court make sense of these terms? ${ }^{23}$ There seem two ways to order search results contemplated by the patent-a strict ordinal ranking from highest to lowest bid, or a more complex algorithm in which bid amount is only one of several factors in determining ranking. But there are at least four different terms describing the ordering: "in accordance with," "determined using," "corresponding to," and in strict "ordinal rank value." Trying to find four different ways in which bid amounts can affect the order of search listings seems futile; these four claims simply do not have four different meanings, and Overture probably did not intend four different things by using four different terms.

Strategic claim drafting can exacerbate this disconnect between the intended meaning of a claim term and the meaning determined by applying the doctrine of claim differentiation. Patent prosecutors often differentiate claims not because they have a different scope in mind for different claims, but because they know that the courts will apply the claim differentiation doctrine in a Markman hearing. These prosecutors bank on courts seeking different meanings for at least some of the claim terms that, in fact, overlap in meaning, thereby unfairly broadening the scope of the patent. It is standard fare at patent continuing legal education programs to encourage prosecutors to arbitrarily choose different words in different claims for just this reason. ${ }^{24}$ If patent lawyers are not actually seeking to differentiate claims, but instead using the claim differentiation doctrine to game the claim construction process, rote application of the canon simply plays into their hands.

22. Complaint, Overture Servs., Inc. v. Google Inc., No. 02-01991 (N.D. Cal. Apr. $23,2002)$.

23. Because the case settled before a Markman order, the court in that case did not have to resolve this issue.

24. This was my experience in the "Strategic Prosecution" session at the University of Texas Advanced Patent Law Institute in October 2006, for example. 


\section{PROPERLY APPLYING CLAIM DIFFERENTIATION}

Does this mean that courts should abandon the doctrine of claim differentiation altogether? I think that would go too far. The canon sometimes gets it right, helping to sustain the rule against importing limitations from the specification into the claim. Sometimes, but not always. Courts should recognize that claim differentiation is a canon that can sometimes help but sometimes hurt the process of determining the meaning of a claim.

It is not enough, of course, to suggest that courts should apply the doctrine only when it helps. Fortunately, there is an identifiable class of cases where claim differentiation is likely to do more good than harm. Those are the cases with "nested" claims, ${ }^{25}$ in which the patentee is attempting to create both broader and narrower claims to hedge its bets against the invalidation of the broader claims. This Part lays out several guidelines that can help courts identify these nested claims and limit application of the doctrine to circumstances in which it helps illumine the proper meaning of the claims.

First, courts should not use the doctrine unless the claims in question are in an independent-dependent relationship. Dependent claims are necessarily narrower versions of an independent claim, since they include all the limitations of the independent claim and add new limitations. Patentees write dependent claims in order to differentiate the scope of their claims, so it will often make sense to use claim differentiation in that context. Indeed, an interpretation of an independent claim that renders it identical to a claim that depends from it would defeat the purpose of having a dependent claim. By contrast, if the claims are not in a dependent relationship-if they are both independent, or if one is dependent not on the other but rather on a third claim not at issue-the superfluity rationale for claim differentiation loses much of its force. ${ }^{26}$ As an initial matter, therefore, it makes sense to limit the doctrine of claim differentiation to claims in a dependent relationship.

25. A nested claim is one in which the broader claim covers a range, and the narrower claim is a subset of that broader range. For example, if claim 1 covers a process that operates at a temperature of 200-400 degrees Fahrenheit, and claim 2 covers the same process at a temperature of 275-325 degrees, the two claims are nested.

26. The Federal Circuit has recognized this, suggesting on several occasions that the justification for applying claim differentiation was strongest when the claims were in a dependent relationship. E.g., Liebel-Flarsheim Co. v. Medrad, Inc. (Liebel-Flarsheim 2004), 358 F.3d 898, 910 (Fed. Cir. 2004); Wenger Mfg., Inc. v. Coating Mach. Sys., Inc., 239 F.3d 1225, 1233 (Fed. Cir. 2001). 
The data I analyzed suggest that courts have generally, but not always, applied the doctrine of claim differentiation in this way. ${ }^{27}$ Of the 69 Federal Circuit cases analyzed, 50 involved claim differentiation arguments based on an independent-dependent relationship, 15 involved arguments based on two independent claims, and 4 involved both. Notably, the Federal Circuit applies claim differentiation $80 \%$ of the time when the claims are in a dependent relationship, and rejects it more than half the time when claims are not.

Table 1

Relationship of Claim Type to the Application of Claim Differentiation in the Federal Circuit

\begin{tabular}{l|llll}
\hline & Accepted & Rejected & Did Not Decide & Total \\
\hline Dependent & 36 & 9 & 5 & 50 \\
Independent & 6 & 9 & 0 & 15 \\
Both & 3 & 1 & 0 & 4 \\
\hline Total & 45 & 19 & 5 & 69 \\
\hline
\end{tabular}

Unfortunately, district courts have not been as clear in limiting application of claim differentiation to claims in a dependent relationship, as Table 2 indicates.

Table 2

Relationship of Claim Type to the Application of Claim Differentiation in the District Courts

\begin{tabular}{l|llll}
\hline & $\underline{\text { Accepted }}$ & $\underline{\text { Rejected }}$ & $\underline{\text { Did Not Decide }}$ & Total \\
\hline Dependent & 35 & 10 & 0 & 45 \\
Independent & 10 & 6 & 5 & 21 \\
Both & 1 & 0 & 0 & 1 \\
\hline Total & 46 & 16 & 5 & 67 \\
\hline
\end{tabular}

During the period surveyed, district courts, like the Federal Circuit, heard claim differentiation arguments much more frequently in the dependent claim context, and were just as likely as the Federal Circuit to accept the argument in that context. However, unlike the Federal Circuit, district courts were more willing to accept claim differentiation arguments in the independent claim and mixed contexts as well. The Federal Circuit's

27. This data is available at http://www.btlj.org/data/articles/22_01_04_data.pdf 
recently issued Curtiss-Wright decision explains why claim differentiation makes more sense in the dependent claim context ${ }^{28}$ and hopefully will encourage district courts to confine their claim differentiation analyses to the dependent claim context.

Second, patent claims that differ in the ranges or group sizes they identify are far more likely to be "nested" than claims that differ only in their descriptive words. Obviously, claim differentiation tells us what we already know here - two different numerical ranges should be interpreted differently. But claim differentiation should also be applied where one claim defines a genus in terms of its non-numerical characteristics and another claim specifies a numerical range. For example, if claim 1 covers "large widgets" 29 and claim 2 covers "the widgets of claim 1 that are at least two cubic meters in size," it is reasonable to infer that "large" in this context encompasses at least some embodiments that are less than two cubic meters. ${ }^{30}$ By contrast, suppose that claim 1 covers "large widgets" and claim 2 covers "sizeable widgets." The doctrine of claim differentiation would instruct us that "sizeable" must mean something different than "large." But it is unlikely that the applicant intended any such gradation between the two claims, particularly if the claims are not in a dependent relationship. Rather, the patentee is more likely hedging her bets, choosing different words for any number of reasons-in case the meaning of one of the claims is unclear to a court, in case one claim is invalidated or held not infringed based on the interpretation of one of the claim terms, or because the drafter hopes to take strategic advantage of the claim differentiation doctrine itself.

Third, courts should apply the doctrine of claim differentiation only where the claims in question are identical except for the elements being

28. Curtiss-Wright Flow Control Corp. v. Velan, Inc., 438 F.3d 1374, 1380-81 (Fed. Cir. 2006).

29. "Widget" has long been the standard term in economics for a mythical product sold in markets that are the subject of economics exams. In the last few years, it has also come to mean an applet used on a computer or mobile phone. See Wikipedia, Widget, http://en.wikipedia.org/wiki/Widget (last visited Nov. 12, 2007). I am referring to the former definition.

30. This principle need not be confined to numerical examples. Thus, in Intamin Ltd. v. Magnetar Technologies, Corp., the Federal Circuit held that where a dependent claim reads "[t]he braking device of claim 1 wherein said intermediary is non-magnetic," the reference to an "intermediary" in claim 1 must include both magnetic and nonmagnetic intermediaries. 483 F.3d 1328, 1335 (Fed. Cir. 2007). But cf. PODS, Inc. v. Porta Stor, Inc., 484 F.3d 1359 (Fed. Cir. 2007) (finding that an element of one claim referring to a "carrier frame" required that the frame have four sides, even though a separate claim specifically identified a four-sided carrier frame, because the specification consistently referred to carrier frames as having four sides). 
differentiated. The superfluity rationale that underlies claim differentiation makes the most sense in such cases, where interpreting the elements at issue to have the same meaning renders the two claims identical in scope and therefore redundant. However, where two claims each have more than one element that differs, there is less reason to apply the doctrine. In those cases, interpreting an element from one claim as having an identical meaning as an element in the second claim will not render the two claims identical in scope. To return to an example used above, two claims otherwise identical except for the use of the term "large widgets" in one claim and "sizeable widgets" in the other claim would indeed be superfluous if large meant the same thing as sizeable, though as I argued above, that is not necessarily a reason to construe them differently. But if one claim referred to "large green widgets" and the other to "sizeable widgets," understanding "large" and "sizeable" to mean the same thing still leaves the two claims meaning different things, since only one claim requires that the widgets be green. The superfluity concern does not apply in that case.

Finally, courts should temper the application of the canon of claim differentiation by checking the results of their claim interpretation against the context and likely scope of the invention. If application of the canon of claim differentiation produces a result at odds with the purpose of the invention or the way it is described in the specification, that fact should raise red flags. Just as courts are reluctant to interpret a claim in a way that excludes the preferred embodiment, because doing so suggests that an interpretation was not intended by the patentee, courts should be reluctant to interpret a claim in a way that departs from the purpose or described scope of the invention. A failure to conduct such a reality check led to the odd result in Phillips, where the patent was construed to encompass embodiments of the invention that would not perform the patent's intended function. Once again, the language of Curtiss-Wright is salutary and should give district courts guidance in applying this rule. ${ }^{31}$

The context-purpose test should not be absolute. To begin, the test requires the court to figure out the purpose of the invention, a difficult task given that applicants sometimes attempt to conceal an invention's purpose in hopes of broadening their claim scope. Sometimes the only way to understand a claim without doing violence to the rules of grammar or syntax is to read the claim to include embodiments of the invention that likely

31. Curtiss-Wright, 438 F.3d at 1381 ("'[T]wo considerations generally govern this claim construction tool when applied to two independent claims: (1) claim differentiation takes on relevance in the context of a claim construction that would render additional, or different, language in another independent claim superfluous; and (2) claim differentiation "can not broaden claims beyond their correct scope."'). 
were not contemplated by the inventor. This will happen where a patent applicant has intentionally gamed the doctrine by putting the broadest numerical range of the invention in a nested dependent claim, for example. In those cases, the law offers one final backstop-invalidity of the claim under the enablement or written description doctrines. ${ }^{32}$

Under the enablement doctrine, a claim that is ultimately interpreted to cover an embodiment the patentee did not intend to cover when the application was filed will often be invalidated for failure to teach a person having ordinary skill in the art (PHOSITA) how to make and use the invention. A great example is Liebel-Flarsheim v. Medrad, Inc. ${ }^{33}$ There, the Federal Circuit in an earlier 2004 appeal applied the doctrine of claim differentiation to conclude that an independent claim that required an "opening" in a medical device did not require a particular type of opening known as a pressure jacket. ${ }^{34}$ On remand, the district court held that the claim as construed was not enabled, and in 2007 the Federal Circuit affirmed. ${ }^{35}$ The patentee's attempt to game the system using the doctrine of claim differentiation succeeded at the claim construction stage, but ultimately resulted in the claim being invalidated.

Sometimes, however, a claim may be enabled even though it was not contemplated by the patentee. In some cases, the PHOSITA could have made and used the broader claimed invention even though the patentee did not in fact think of it. Here enablement will not limit the broadening of claims, but the written description doctrine may step in to solve the problem. The written description doctrine requires the patentee to demonstrate that she was in fact in possession of the invention at the time of filing. ${ }^{36}$ While written description cases outside the DNA context have generally involved patentees who changed their claims after filing to cover an embodiment that they did not possess as of the filing date, the doctrine has since been expanded to cover originally-filed claims outside of biotechnology ${ }^{37}$ and one could see the judicial expansion of the claim to cover scope unanticipated by the patentee as akin to the patentee's improper broadening of claims by amendment, in both cases resulting in invalidity of the broader claim.

32. 35 U.S.C. $\S 112, \uparrow 1(2000)$.

33. Liebel-Flarsheim Co. v. Medrad, Inc. (Liebel-Flarsheim 2007), 481 F.3d 1371, 1374-75 (Fed. Cir. 2007).

34. Liebel-Flarsheim 2004, 358 F.3d at 912.

35. Liebel-Flarsheim 2007, 481 F.3d at 1371.

36. Gentry Gallery, Inc. v. Berkline Corp., 134 F.3d 1473 (Fed. Cir. 1998).

37. See, e.g., Lizardtech, Inc. v. Earth Resource Mapping, Inc., 424 F.3d 1336 (Fed. Cir. 2005). 
The application of the enablement or written description doctrines to solve problems created by applying claim differentiation should be a last resort. Both doctrines require the court to determine whether the patentee claims something beyond what she in fact possessed at the time of filing, a difficult task for the court. A better approach is to solve most of these problems by judicious application of the claim differentiation canon.

\section{CONCLUSION}

Properly cabined, claim differentiation should not render claims invalid merely because the patentee did not possess the invention the court has now decided she claimed. Instead, it should result in narrower but valid claims, except in cases in which the patentee has strategically sought to expand those claims beyond what the patent's specification will support. A canon of claim construction that is not absolute, but sensitive to the context of the invention and the way in which the words in question interact, will help courts achieve the elusive goal of interpreting claims to give the patentee effective protection while discouraging gamesmanship and avoiding absurd results. I have offered several principles for applying the doctrine in such a context-sensitive manner. Recent Federal Circuit decisions suggest that the court is sensitive to the problem and mostly applies the doctrine appropriately, despite the aberration of Phillips. Hopefully, over time, district courts will apply the doctrine more judiciously as well. 
BERKELEY TECHNOLOGY LAW JOURNAL 